\title{
ХИМИЧЕСКИЙ СОСТАВ СУЛЬФИДНО-ИЛОВОЙ ГРЯЗИ ОЗ. БОРМАШОВОЕ
}

\author{
Павлов И.А. ${ }^{1,2}$
}

${ }^{1}$ ФГБУН Байкальский институт природопользования СО РАН, Улан-Удэ, Россия

${ }^{2}$ ФГБОУ ВПО Бурятский государственный университет имени Доржи Банзарова, Улан-Удэ, Россия

info@binm.ru,univer@bsu.ru

DOI: 10.26902/ASFE-11_77

Республика Бурятия богата разнообразными гидроминеральными ресурсами, многие из которых открыты и впервые исследованы при проведении геолого-гидрогеологического картирования территории в 1950-1980-е годы [1]. В долине р. Баргузин широко известны минеральные озера, одним из которых является озеро Бормашовое. Многие из минеральных озер располагают запасами целебных грязей. В настоящее время детально изучены механизмы действия грязевых процедур на рецепторы кожи, что приводит к рефлекторной активации процессов биорегуляции многих систем организма [2]. Известно, что положительное воздействие грязи на организм человека реализуется за счет теплового и химического факторов [3]. Многочисленные химические факторы грязи, активируемые теплом, а именно минералы, витамины, биогенные стимуляторы, гормоноподобные вещества, действуют непосредственно на подлежащие ткани и на месте воздействия образуют так называемую «мантию», которая способна пролонгировать лечебное действие грязи [4].

Вода в озере Бормашовое несколько солоноватая. В формировании водно-солевого режима водоема принимают участие атмосферные осадки и грунтовые воды современных и верхнечетвертичных отложений. По солевому питанию преимущество остается за грунтовыми водами, с которыми в него поступают основные микроэлементы, в том числе сульфаты. Грязь озера Бормашовое является бальнеологической разновидностью пелоидов низкоминерализованные высокозольные слабосульфидные лечебные сапропели.

Таким образом, нами были изучены физико-химические свойства лечебной грязи озера Бормашовое. Средний показатель влажности составляет $74 \%$. Средняя зольность составила $85 \%$, что позволяет отнести лечебную грязь к высокозольным лечебным грязям. Электропроводность - 720-760 мкСм/см., что говорит о высокой проводимости электрического тока, характеризующий большое содержание солей. $\mathrm{pH}$. среды составило 7,8 относится к слабощелочным грязям. Именно такая среда способствует образованию и накоплению в грязи сульфидов. Определены такие катионы как: $\mathrm{Na}^{+}, \mathrm{NH}_{4}{ }^{+}, \mathrm{K}^{+}, \mathrm{Mg}_{2}{ }^{+}, \mathrm{Ca}_{2}{ }^{+}$. Анионы: $\mathrm{F}^{-}, \mathrm{Cl}^{-}, \mathrm{NO}_{2}^{-}, \mathrm{Br}^{-}, \mathrm{NO}_{3}^{-}, \mathrm{HCO}_{3}^{-}$. Также были идентифицированы следующие элементы: $\mathrm{Al}, \mathrm{Cr}, \mathrm{Mn}, \mathrm{Fe}, \mathrm{Cu}, \mathrm{Zn}, \mathrm{Ni}, \mathrm{Pb}, \mathrm{Ba}, \mathrm{Cd}$. Был определен жирно-кислотный состав липидной фракции пелоида. В этом составе ведущими кислотами стали: пальмитиновая, миристиновая и стеариновая кислоты, обладающие лечебными свойствами.

\section{Литература}

1. Плюснин А.М., Украинцев А.В., Чернявский М.К., Перязева Е.Г., Ангахаева Н.А. Факторы и процессы образования соленого озера на берегу Байкала // Водные ресурсы. 2021. Т. 48. № 2. С. 194-206.

2. Илли Я.Р., Гончарова Е.Н. Использование сапропелевой грязи в лечебной практике // В сборнике: Наукоемкие технологии и инновации Международная научно-практическая конференция (XXII научные чтения). - 2016. - С. 29-33.

3. Андреева И.Н., Andreeva I.N., Степанова О.В., Поспеева Л.А., Тимошин С.А. Лечебное применение грязей (учебное пособие) // Физиотерапия, бальнеология и реабилитация. - 2004. - № 5. - С. 46.

4. Королев Д.Ю., Данилина Т.Ф., Сабанов В.И. Лечебные грязи и особенности их применения в клинической практике // В сборнике: Актуальные вопросы экспериментальной, клинической и профилактической стоматологии Конференция, посвященная 45-летию стоматологического факультета Волгоградского государственного медицинского университета. - 2006. - С. 144-150. 